\title{
EFEKTIFITAS MODEL PEMBELAJARAN INQUIRY BASED LEARNING DALAM MENINGKATKAN PEMBELAJARAN BAHASA INDONESIA SISWASMP KECAMATAN SABBANGPARU
}

\author{
Sri Wahyuni ${ }^{1}$, Arisa ${ }^{2}$ \\ Program Studi Pendidikan Bahasa dan Sastra Indonesia \\ STKIP Puangrimaggalatung Sengkang ${ }^{1,2}$ \\ yuni_core@yahoo.com ${ }^{1}$ \\ Submit, 13-05-2018 Accepted, 15-06-2018 Publish, 27-06-2018
}

\begin{abstract}
ABSTRAK
Penelitian ini bertujuan membahas efektifitas model pembelajaran inquiry based learning dalam meningkatkan pembelajaran bahasa Indonesia siswa SMP di Kecamatan Sabbangparu.Pengambilan data dalam penelitian ini, dilaksanakan melalui dua siklus. Subjek penelitian adalah guru dan siswa kelas VIII dengan jumlahsiswa 32 orang, terdiri atas 20 laki-laki dan 12 perempuan.Hasil analisis belajar setelah diterapkan model inkuiri pada siswa kelas SMPNegeri2SabbangparuKabupatenWajo yaitu pada tahap prasiklus siswa yang tuntas dengan nilai $\geq 75$ sebanyak 0 siswa dengan persentase ketidak tuntasan 100\%.Pada siklus I hasilbelajar siswa meningkat, yaitu sebanyak 20 siswa dengan presentase $63 \%$ tuntasbelajar dengan nilai $\geq 75$.Pada siklus II juga terjadi peningkatan yaitu siswa yangtuntas dengan nilai $\geq 75$ sebanyak 28 siswa dengan persentase $88 \%$.Jadi siswa yangtuntas belajar mengalami peningkatan dari $68 \%$ sampai $88 \%$. Berdasarkan hasilpenelitian, dapat disimpulkan bahwa penerapan modelinkuiriefektif meningkatkanpembelajaran bahasa Indonesia siswa SMP di Kecamatan Sabbangparu khususnya pada materi menulis teks argumentasi.Setelah adanya penelitian tersebut, disarankan guru hendaknya senantiasamengawasi kelas untuk memotivasi keaktifan siswa dan memberikan bimbingansecara individu maupun kelompok.
\end{abstract}

Kata Kunci: Efektifitas, Inkuiri, Siswa, Sabbangparu

\section{ABSTRACT}

This study aims to discuss the effectiveness of learning inquiry-based learning model in improving the learning of Indonesian junior high school students in Sabbangparu District. The data collected in this study, carried out through two cycles. Research subjects were teachers and students of class VIII with a total of 32 students, consisting of 20 males and 12 females. The result of learning analysis after applied inkuiri model in class student of SMP Negeri 2 Sabbangparu Wajo Regency that is at student prasiklus stage which complete with value $\geq 75$ counted 0 student with percentage of $100 \%$ unfinished. In the first cycle, the students' learning achievement increased, that is 20 students with $63 \%$ complete percentage of study with a value of $\geq 75$. In cycle II also an increase that is a complete student with a value of $\geq 75$ as many as 28 students with $88 \%$ percentage. So complete students learn to increase from $68 \%$ to $88 \%$. Based on the results of the research, it can be concluded that the application of inquiry model 
effectively improves the learning of Indonesian junior high school students in Sabbangparu sub-district, especially on the matter of writing argumentation text. After the existence of the research, it is suggested that teachers should always supervise the class to motivate students' activeness and provide individual and group guidance.

Keywords: Effectiveness, Inquiry, Students, Sabbangparu

\section{PENDAHULUAN}

Pembelajaran seharusnya menjadi aktivitas bermakna yakni pembebasan untuk mengaktualisasi seluruh potensi kemanusiaan, bukan sebaliknya. Pertanyaannya bagaimana menemukan cara terbaik menciptakan pembelajaran bermakna? Proses belajar merupakan proses perubahan seseorang yang dapat dinilai hasilnya dari perubahan yang dilakukan. Dalam proses belajar yang baik dibutuhkan suatu strategi pembelajaran yang tepat sehingga proses belajar dapat dikatakan berhasil dengan baik (Sanjaya, W 2008).

Materi pelajaran tidak selamanya dapat diajarkan dengan menggunakan model pembelajaran yang sama, sehingga seorang guru harus bisa menguasai berbagai model pembelajaran yang kemudian disesuaikan dengan materi ajar. Oleh karena itu diperlukan suatu model pembelajaran yang dapat membuat siswa aktif sehingga dapat meningkatkan hasil belajar bahasa Indonesia siswa (Muslimin, 2010).

Berdasarkan observasi awal peneliti,guru-guru SMP Kecamatan Sabbangparu mayoritas masih menggunakan model pembelajaran konvensional, hal tersebut membuat siswa masih pasif dalam proses pembelajaran dengan hasil belajar yang masih tergolong rendah, melihat hal itu peneliti mencoba untuk menerapkan model pembelajaran inkuiri untuk melihat peningkatan hasil belajar siswa. Model inquiry didefinisikan sebagai suatu rangkaian kegiatan belajar yang melibatkan secara maksimal seluruh kemampuan siswa untuk mencari dan menyelidiki masalah secara sistematis, kritis, logis, dan analisis sehingga mereka dapat merumuskan sendiri penemuan mereka dengan rasa percaya diri (Rusman, 2012).

Model pembelajaran Inkuiri memungkinkan para peserta didik menemukan sendiri informasi-informasi yang diperlukan untuk mencapai tujuan belajarnya. Model ini melibatkan peserta didik dalam proses-proses mental untuk penemuan suatu konsep berdasarkan informasi-informasi yang diberikan guru. Model Inkuiri merupakan model pembelajaran yang berupaya menanamkan dasar-dasar berpikir ilmiah pada diri siswa, sehingga dalam proses pembelajaran ini siswa lebih banyak belajar sendiri, 
mengembangkan kreatifitas dalam memecahkan masalah (Martini dan Nugroho, 2013). Siswa benar-benar ditempatkan sebagai subjek yang belajar.Peranan guru dalam pembelajaran dengan metode Inkuiri adalah sebagai pembimbing dan fasilitator.Tugas guru adalah memilih masalah yang perlu disampaikan kepada kelas untuk dipecahkan.

\section{METODE PENELITIAN}

Lokasi dalam penelitian ini yaitudisekolah menengah pertama yang ada diSabbangparu Kabupaten Wajo yakni SMP Negeri 2 Sabbangparu tahun ajaran 2017/2018. Peubah yang diamati; 1) faktor aktivitas yaitu melihat bagaimana aktivitas siswa dalam proses belajar mengajar berlangsung, 2) faktor hasil yaitu melihat apakah pembelajaran Inquiry Based Learningdapat meningkatkan hasil belajar siswa. Model peneitian yang digunakan adalah penelitian tindakan kelas (classroom action research) yang meliputi empat tahap pelaksanaannya yaitu perencanaan, tindakan, observasi/evaluasi dan refleksi.

Pengumpulan data dilakukan dengan teknik dokumentasi, observasi, dan tes. Teknik dokumentasi digunakan untuk merekam proses belajar mengajar berdasarkan instrumen observasi. Sedangkan tes digunakan untuk mengetahui hasil belajar. Data yang diperoleh dari hasil penelitian selanjutnya dianalisis secara kuantitatif dan kualitatif. Untuk analisis kuantitatif digunakan analisis deskriptif yang terdiri atas nilai rata-rata, nilai tertinggi, nilai terendah yang diperoleh siswa pada tes siklus. Data hasil observasi dianalisis secara kualitatif untuk melihat rata-rata dan persentase aktivitas siswa pada saat pembelajaran.

\section{HASIL PENELITIAN}

Penelitian ini dilaksanakan di SMP Negeri 2Sabbangparu Kabupaten Wajo pada siswa kelasVIII.A semester genap tahun pelajaran 2017/2018dengan jumlah siswa 32 orang dengan mengangkat materi tentang teks Argumentasi.

\section{Prasiklus}

Hasil tes prasiklus menunjukkan bahwa siswa yang mencapai ketuntasan nilai (nilai $\geq 75$ ) sebanyak 0 siswa atau sebesar $0 \%$ dari total 32 siswa. Sisanya sebanyak 32 siswa atau sebesar $100 \%$ dari total 32 siswa belum mencapai ketuntasan nilai (nilai<75). kelemahan yang ditemukan pada siswa dalam menulis teks argumentasitahap 
prasiklus adalah siswa kurang memaparkan kelogisan alasan, kecukupan buktipenunjang, ketepatan penulisan ejaan, dan siswa cenderung menulis paragraphpersuasif yang di akhir kalimat terdapat kalimat ajakan untuk melakukan sesuatu.

Selanjutnya dilakukan wawancara dengan guru kelas VIII.A diperoleh bahwa guru mengajar dengan menggunakan model pembelajarankonvensional. Ketika pembelajaran, siswa cenderung pasif dan hanya bersifatpenerima informasi. Jadi, dapat disimpulkan proses pembelajaran masihmenggunakan model pembelajaran yang berpusat pada guru dan aktivitas siswadalam pembelajaran masih kurang karena pembelajaran masih didominasi oleh guru.

\section{Pelaksanaan Siklus I}

Pembelajaran keterampilan teks argumentasi pada siklus 1 terdiri dariempat tahap yaitu perencanaan, tindakan, pengamatan, dan refleksi hasil tindakan.

\section{Perencanaan}

Perencanaan pembelajaran menulis teks argumentasi melalui penerapanmodel pembelajaran inkuiri dilakukan secara kolaboratif antara peneliti dengan guru matapelajaran bahasa Indonesia kelas VIII SMP Negeri 2Sabbangparu Kabupaten Wajo.Perencanaan inimeliputi:

1. Menyusun Rencana Perbaikan Pembelajaran (RPP) pokok bahasan.

2. Menyusun Lembar Kerja Siswa (LKS) pokok bahasan menulis teks argumentasi dengan menggunakan metode Inqury Based Learningyang dibuatberdasarkan Rencana Pelaksanaan Pembelajaran (RPP) dengan rincian LKSyang dibuat berdasarkan Rencana Pelaksanaan Pembelajaran (RPP)prasiklus.

3. Menyusun pedoman wawancara, observasi, dan dokumentasi.

Untuk mengetahui ketuntasan belajar siswa peneliti menggunakan pedoman yang digunakan oleh pihak SMP Negeri 2Sabbangparu Kabupaten Wajosebagai berikut:

1. Daya serap perorangan, seorang siswa dikatakan tuntas jika telah mencapai nilai $\geq 75$

2. Daya serap klasikal, suatu kelas dikatakan berhasil jika terdapat minimal $65 \%$ siswa mencapai nilai $\geq 75$ 
Tabel 1.

Kriteria Ketuntasan Hasil Belajar Siklus 1

\begin{tabular}{ccccc}
\hline \multirow{2}{*}{ Pencapaian $(\%)$} & \multicolumn{2}{c}{ Kualifikasi } & \multirow{2}{*}{ Kategori Nilai } & Tingkat Keberhasilan \\
\cline { 2 - 3 } & Angka & Huruf & & \\
\hline $80-100$ & 5 & A & Baik Sekali & Berhasil \\
$65-79$ & 4 & B & Baik & Berhasil \\
$56-64$ & 3 & C & Cukup & Tidak Berhasil \\
$40-55$ & 2 & D & Kurang & Tidak Berhasil \\
$20-39$ & 1 & E & Gagal & Tidak Berhasil \\
\hline
\end{tabular}

Berdasarkan hasil penelitian di siklus 1 menunjukkan bahwa siswa yang mencapai ketuntasan nilai (nilai $\geq 75$ ) sebanyak 20 siswa sebesar $63 \%$ dari total siswa 32 siswa. Sisanya sebanyak 12siswa sebesar $37 \%$ dari 32 siswa belum mencapai ketuntasan (nilai <70). Hasiltersebut lebih baik dibandingkan dengan hasil pada tahap prasiklus, sehinggaketerampilan menulis argumentasi pada siklus I dapat dikatakan meningkat.Namun,penelitian di siklus I ini tidak berhasil atau belum tuntas karena belum mencapaistandar keberhasilan secara klasikal.Hasil tersebut masuk dalam kategori nilai cukupdan tingkat keberhasilan tidak berhasil.Aspek penilaian yang masih kurang dalam menulis wacana argumentasi yaitu,kelogisan alasan, kecukupan bukti penunjang, dan ejaan.Aspek tersebut masihbanyak siswa yang medapat skor dibawah standar ketuntasan minimum.Oleh sebabitu, perlu adanya perbaikan dengan melaksanakan tindakan pada siklus II.

\section{Observasi}

Hasil observasi di siklus 1 yaitu terdapat beberapa aspek yang mendapatskor kurang diantaranya guru kurang mengaitkan materi dengan pengetahuan lainyang relevan dan kurang menunjukkan hubungan antar pribadi yang kondusif.Dengan demikian, diperlukan perbaikan pada siklus II untuk mencapai hasil yang lebihsempurna.Sedangkan untuk melihat kriteria keefektifan model pembelajaran inkuiri di siklus 1 adalah sebagai berikut: 
Tabel 2.

Kriteria Penilaian Keefektifan Model Pembelajaran Inkuiri Siklus I

\begin{tabular}{ccccc}
\hline \multirow{2}{*}{ Pencapaian $(\%)$} & \multicolumn{2}{c}{ Kualifikasi } & Kategori Nilai & Tingkat Keberhasilan \\
\cline { 2 - 3 } & Angka & Huruf & & \\
\hline $80-100$ & 5 & A & Baik Sekali & Berhasil \\
$65-79$ & 4 & B & Baik & Berhasil \\
$56-64$ & 3 & C & Cukup & Tidak Berhasil \\
$40-55$ & 2 & D & Kurang & Tidak Berhasil \\
$20-39$ & 1 & E & Gagal & Tidak Berhasil \\
\hline
\end{tabular}

Berdasarkan hasil penelitian diperoleh datapersentase proses pembelajaran dengan menggunakan metode Inkuiri sebesar 66\%.Hal ini berarti proses pembelajaran dengan menggunakan metode Inkuiri termasukpada kriteria baik.Akan tetapi, siswa masih kurang dalam komponen pemecahanmasalah berpasangan. Hal ini terjadi karena siswa merasa malu, takut untuk berbagiatau menyunting hasil kerja teman sebaya, dan masih bingung cara menyunting yangbenar. Dengan begitu, diperlukan perbaikan pada siklus II.

\section{Refleksi}

Kegiatan rekleksi dilakukan peneliti dan guru kelas setelah prosespembelajaran. Berdasarkan hasil penugasan, observasi, dan wawancara pada siklus Idiketahui bahwa terdapat peningkatan aktivitas belajar siswa dibandingkan sebelumtindakan.Namun, penelitian di siklus I ini masih perlu ditingkatkan lagi untukmenyempurnakan pembelajaran dengan menggunakan modelinkuiri untukmeningkatkan keterampilan menulis teksargumentasi.Kekurangan tersebutterdapat pada aspek kelogisan alasan, kecukupan bukti penunjang, dan ejaan.

\section{Pelaksanaan Siklus II}

Siklus II merupakan upaya perbaikanberdasarkan hasil analisis pada siklus I.

\section{Perencanaan}

1. Menyusun Rencana Perbaikan Pembelajaran (RPP) pokok bahasanteks argumentasi.

Rencana Perbaikan Pembelajaran (RPP) disusun untuk 1 kali pertemuanpada siklus II 
2. Menyusun Lembar Kerja Siswa (LKS) pokok bahasan teksargumentasi.

Penerapan Metode inkuiri untuk meningkatkan keterampilan menulisteks argumentasi yang dibuat berdasarkan Rencana PerbaikanPembelajaran (RPP) dengan rincian LKS siklus II dibuat berdasarkan RPPsiklus I.

\section{Tindakan Siklus II}

Guru membagi siswa dalam beberapa kelompok, setiap kelompok terdiri dariempat siswa. Untuk setiap kelompok, guru membebaskan siswa memilih sendiri.Setelah siswa duduk dalam kelompok masing-masing guru membagikan LKS danmemerintah siswa untuk memngerjakan secara berkelompok.Kegiatankerja kelompok dengan teman sebaya pada siklus II ini megalami peningkatan dari pada siklus I. Kegiatan siklus II inidiskusi terlihat tenang dan tidak gaduh.Dalam kegiatan siklus II ini guru juga turut membimbing siswa jika ada siswa yangbertanya tentang materi teks argumentasi.Berikut ini hasil menuliswacana argumentasi siswa SMP Negeri 2Sabbangparu Kabupaten Wajosiklus II.Hasil penelitian menunjukkan bahwa siswa yang mencapai ketuntasan nilai (nilai $\geq 75$ ) sebanyak 28 siswa atau sebesar $88 \%$ dari total 32 siswa. Sisanya sebanyak 4siswa atau sebesar 12\% dari total 32 siswa belum mencapai ketuntasan nilai (nilai<75).

Aspek penilaian teks argumentasi yang mengalami peningkatan yaitu isikarangan atau pemberian judul, bukti penunjang dan organisasi karangan.Oleh sebab itu bisa dikatakan penelitian pada siklus II ini sudahmencapai standart ketuntasan minimal klasikal, sehingga tidak perlu dilaksanakanperbaikan lagi.

\section{Observasi}

Berdasarkan data dari tabel observasi guru dan siswa dalam pelaksanaanpembelajaran, diperoleh data persentase aktivitas guru adalah $96 \%$ dan siswa 97\%.Halini berarti aktivitas guru masuk pada kriteria nilai berhasil atau baik sekali danaktivitas siswa masuk pada kriteria nilai berhasil atau baik sekali.Hasil tersebut lebihbaik dibandingkan dengan hasil pada tahap siklus I, sehingga keterampilan menulisteks argumentasi pada siklus II dapat dikatakan meningkat.Sesuai dengan kriteriaketuntasan, persentase aktivitas guru dan keaktifan siswa tersebut dikatakan sudahmencapai ketuntasan belajar secara klasikal yaitu 96\% dan 97\%. 


\section{Refleksi}

Pembelajaran siklus II yang telah dilakukan sudah sesuai dengan standarketuntasan yang telah direncanakan. berdasarkan hasil analisis ketuntasan belajarpada siklus II yang menunjukkan bahwa siswa yang mengikuti post-testdengan jumlah 32 siswa yang tuntas secara perorangan sejumlah 28 siswa dan siswayang tidak tuntas secara perorangan sebanyak 4 siswa. Persentase ketuntasan hasilbelajar melalui metode inkuiri pada siklus II sebesar 88\%.Peningkatan tersebutterjadi karena hasil tulisan siswa sudah dapat menunjukkan bukti penunjang danorganisasi karangan dengan baik.

Suasana pembelajaran di kelas juga semakin kondusif dan aktifsesuai denganrencanayang telah dibuat.Keaktifan guru semakin tampak dibandingkan siklus I denganpersentase sebesar 96\%.Tingkat keaktifan siswa juga semakin merata biladibandingkan dengan pembelajaran siklus I. Sesuai dengan kriteria keberhasilan,persentase tersebut dikatakan sudah mencapai ketuntasan belajar secara klasikal yaitu97\%. Begitu juga proses pembelajaran menggunakan metode inkuiri semakinmeningkat dengan persentase 97\%. Berdasarkan data di atas, persentase observasisudah maksimal dan ketuntasan belajar sudah memenuhi standar ketuntasan klasikal,maka penelitian dapat dihentikan. Bagi 4 siswa yang belum mencapai criteriaketuntasan minimal (KKM) akan diberikan bimbingan individu. Kekurangan yangterjadi di siklus I sudah dapat teratasi pada siklus II.

\section{PEMBAHASAN}

\section{Ketuntasan Hasil Belajar Siswa}

Penelitian ini menggunakan Penelitian Tindakan Kelas (PTK) yang bertujuan untuk meningkatkan aktivitas dan hasil belajar. Penelitian Tindakan Kelas (PTK) merupakan suatu pencermatan terhadap kegiatan belajar berupa sebuah tindakan, yang sengaja dimunculkan dan terjadi dalam sebuah kelas secara bersama (Suharsimi, 2012).

Berdasarkan hasil analisis selama pembelajaran menggunakan metode Inkuiridiperoleh data perbandingan setiap siklus.Data perbandingan setiap siklusdapat dilihat pada tabel berikut. 
Tabel 3

Hasil Perbandingan Menulis Teks Argumentasi Persiklus

\begin{tabular}{ccccccccc}
\hline \multirow{2}{*}{ No } & Perolehan & \multicolumn{2}{c}{ Prasiklus } & \multicolumn{2}{c}{ Siklus I } & \multicolumn{2}{c}{ Siklus II } & \multirow{2}{*}{ Ket } \\
\cline { 3 - 7 } & Nilai & $\begin{array}{c}\text { Jumlah } \\
\text { Siswa }\end{array}$ & Presentase & $\begin{array}{c}\text { Jumlah } \\
\text { Siswa }\end{array}$ & Presentase & $\begin{array}{c}\text { Jumlah } \\
\text { Siswa }\end{array}$ & Presentase & \\
\hline 1 & Nilai $\geq 75$ & 0 & $0 \%$ & 20 & $63 \%$ & 28 & $88 \%$ & T \\
2 & Nilai<75 & 32 & $100 \%$ & 12 & $37 \%$ & 4 & $12 \%$ & TT \\
\hline \multicolumn{2}{c}{ Jumlah } & 32 & $100 \%$ & 32 & $100 \%$ & 32 & $100 \%$ & \\
\hline
\end{tabular}

Berdasarkan tabel di atas, pembelajaran bahasa Indonesia denganmenggunakan metode inkuiri mengalami peningkatan dari siklus ke siklusberikutnya. Berdasarkan hasil penelitian dapat dilihat bahwa tahap prasiklus siswayang mendapat nilai $\geq 75$ (tuntas) sebanyak 0 siswa $(0 \%)$, sedangkan siswa yangmendapat nilai <75 (tidak tuntas)sebanyak 32 siswa (100\%). Pada siklus I setelahditerapkan metode inkuiri dalam pembelajaran menulis wacana argumentasiterjadipeningkatan hasil belajar. Siswa yang mendapat nilai $\geq 75$ (tuntas) sebanyak 20 siswa (63\%) dan yang belum mencapai ketuntasan hasil belajar berkurang menjadi 12 siswa (37\%) Pada siklus II juga menerapkan metode inkuiri dalam pembelajaran menulisteks argumentasi yang direncanakan lebih cermat dan disempurnakan sehinggahasil yang didapat lebih baik dan mengalami peningkatan dari siklus sebelumnya.Hasilnya siswa yang mendapat nilai $\geq 75$ (tuntas) sebanyak 28 siswa (88\%),sedangkan yang belum mencapai ketuntasan sebanyak 4 siswa (12\%)

Uraian tersebut menunjukkan bahwa antara prasiklus ke siklus I terjadipeningkatan sebanyak 20 siswa.Demikian juga antara siklus I ke siklus II jugamengalami peningkatan sebanyak 8 siswa.Berdasarkan hasil tersebut makaketuntasan belajar secara klasikal telah tuntas karena telah mencapai $88 \%$ dimanastandar ketuntasan minimum secara klasikal adalah 80\%.Dengan demikian dapatdisimpulkan bahwa keterampilan menulis wacana argumentasi dapat meningkatsetelah diterapkan pembelajaran dengan menggunakan metode inkuiri.

\section{Aktivitas Guru dan Siswa dalam Pembelajaran}

Aktivitas guru dalam pelaksanaan pembelajaran menulis teks argumentasidalam penelitian ini dikatakan baik pada siklus I dengan persentase $84 \%$ dan dikatakan baik sekali, pada siklus II dengan persentase 96\%. Guru menguasai materipelajaran, 
memberikan motivasi, mengaitkan materi dengan pengetahuan yangrelevan, guru mengaitkan materi argumentasi dengan media pembelajaran.

Aktivitas siswa terdapat dua macam yaitu proses pembelajaran metodeI inkuiri dan keaktifan siswa. Kegiatan pembelajaran melalui metode Inkuirimembuat siswa kreatif, memecahkan masalah dengan teman sebaya, dan termotivasidalam pembelajaran menulis wacana argumentasi. Proses pembelajaran metodeInkuiri sudah baik dengan persentase proses pembelajaran metode Inkuiri $66 \%$ pada siklus I dan $97 \%$ pada siklus II. Dalam proses pembelajaran metode Inkuiriini, siswa sangat serius dan aktif dalam tahap Sebaya, Media, Aplikasi, Remidi, dan Tes sehingga terlihat peningkatan pada siklus II. Ketertiban dan keaktifan siswa jugasangat baik.Pada siklus I persentase keaktifan siswa $69 \%$ dan pada siklus II $97 \%$.

Tabel.4

Persentase aktifitas guru dan siswa dalam proses pembelajaran

\begin{tabular}{ccccc}
\hline No. & Tindakan & $\begin{array}{c}\text { Keaktifan } \\
\text { Guru }(\%)\end{array}$ & $\begin{array}{c}\text { Keaktifan Siswa } \\
(\%)\end{array}$ & $\begin{array}{c}\text { Proses } \\
\text { Pembelajaran (\%) }\end{array}$ \\
\hline & & & Aktif $=69 \%$ & Aktif $=66 \%$ \\
1. & Siklus I & $84 \%$ & Kurang aktif $=31 \%$ & Kurang aktif=34\% \\
2. & Siklus II & $96 \%$ & Aktif $=97 \%$ & Aktif $=97 \%$ \\
& & & Kurang Aktif $=4 \%$ & Kurang Aktif $=3 \%$ \\
\hline
\end{tabular}

\section{SIMPULAN}

1. Penerapan Model pembelajaran berbasis penemuan (Inkuiri) dalam pembelajaran bahasa Indonesia khususnya materi menulis teks argumentasidapat meningkatkan kemampuan siswa menulis teks argumentasi pada siswakelas VIII SMP Negeri 2 Sabbangparu Kabupaten Wajo. Hal ini bisa dilihat dari hasil menulisteks argumentasi siswa yang semakin meningkat baik dari siklus I sampaipada siklus II. Siswa menjadi kreatif, aktif, dan percaya diri. Hal ini disebabkanadanya penggalian kemampuan siswa melalui model pembelajaran Inkuiri. Siswa juga lebih mudah dalam menuangkan idenya sehingga pendapatmereka dapat tersalurkan.

2. Hasil belajar menulis teks argumentasi setelah diterapkan model pembelajaran inkuiri pada siswa kelas VIII SMP Negeri 2 Sabbangparu Kabupaten Wajo mengalami peningkatan. PadaPrasiklus ketuntasan hasil belajar siswa 0\%, pada siklus I meningkat $63 \%$, danpada siklus II juga meningkat $88 \%$ sehingga secara 
klasikal memenuhi criteriaketuntasan Minimal (KKM) SMP Negeri 2 Sabbangparu. Hal ini ditunjangdengan keaktifan guru yang meningkat dari $84 \%$ menjadi $96 \%$.

\section{DAFTAR PUSTAKA}

Arikunto, Suharsimi. (2012). Prosedur Penelitian Suatu Pendekatan Praktis. Jakarta: Bina Angkasa.

Muslimin, M. (2010). Model Pembelajaran Kooperatif. Surabaya: Universitas Negeri Surabaya.

Ratri, A., Martini, K dan Nugroho, A. (2013). Pembelajaran Kimia Dengan Metode Inqury Terbimbing Dilengkapi Kegiatan Laboratorium Real Dan Virtual Pada Pokok Bahasan Pemisahan Campuran. Jurnal Pendidikan Kimia (JPK), 2 (2), 44-49.

Rusman. (2012). Model-model Pembelajaran. Jakarta: Raja Grafindo Persada

Sanjaya W. (2008). Strategi Pembelajaran, Jakarta: Kencana Prenada. 